Tema : Pancasila sebagai dasar Pengembangan Ilmu

\title{
PENYIMPANGAN NILAI PANCASILA DALAM PENYALAHNGGUNAAN TEKNOLOGI SPY CAM ( HIDDEN CAMERA )
}

\author{
Andreas M Simanullang ( 2101010003 ) \\ Samuel Jefry Marthin ( 2101010060 ) \\ Universitas Maritim Raja Alih Haji ( UMRAH )
}

\begin{abstract}
ABSTRAK
Pembangunan nasional merupakan usaha peningkatan kualitas manusia dan masyarakat Indonesia yang dilakukan secara berkelanjutan, berlandaskan kemampuan nasional, dengan memanfaatkan kemajuan ilmu pengetahuan dan teknologi serta memperhatikan tantangan perkembangan global.

Dalam penerapannya, setiap bidang ilmu pengetahuan di Indonesia haruslah berdasarkan Pancasila. Di era saat ini, semakin gencar dilakukan peningkatan teknologi baik dari segi kualitas maupun kuantitas. Dalam hal teknologi kamera, pada awal penemuannya kamera merupakan sebuah alat yang dapat merekam atau memproyeksikan suatu objek menjadi sebuah gambar. Namun ukuran kamera dulunya bisa mencapai lebih dari tubuh seorang dewasa. Digenerasi selanjutnya, ukuran kamera berubah pesat menjadi sekitar genggaman dua tangan orang dewasa dan fungsinya juga turut meningkat yaitu yang dulunya hanya bisa merekam gambar, kini bisa juga merekam suara ( video ). Dan pada saat ini memang ukuran kamera pada umumnya adalah sebesar genggaman dua tangan orang dewasa ( ada juga yang lebih kecil dengan produk yang sama ). Namun ada juga yang dinamakan CCTV yaitu kamera yang dibuat khusus untuk keamanan. Berbeda dengan kamera pada umumnya yang mementingkan kualitas, CCTV tidak difokuskan pada kualitas namun untuk ketahanan merekam dan tahan cuaca apapun ( karena ada CCTV outdoor ).

Setelah penemuan CCTV, dilakukanlah perubahan oleh orang yang belum diketahui profilnya yakni mengonversi ukuran kamera menjadi lebih kecil dan berbagai bentuk, salah satu bentuk yang paling populer adalah Spy Cam pada balpoint. Sesungguhnya Spy Cam dapat digunakan untuk kebutuhan positif seperti menjebak pencuri ataupun mengawasi pergerakan pelaku kejahatan. Digunakannya Spy Cam karena ada beberapa kemungkinan jika pada tempat tertentu tidak bisa mengoperasikan CCTV. Dalam artikel ini disoroti penyalahgunaan teknologi Spy Cam yang mengakibatkan penyimpangan nilai Pancasila
\end{abstract}




\section{PENDAHULUAN}

Oleh tiga tokoh besar, dibahas dibeberapa pertemuan dan dua diantaranya adalah sidang besar, melahirkan lima buah kalimat biasa namun maknanya dapat menyatukan sebuah negara dengan 17.000 pulau, 6 agama resmi, 1.340 suku dan keberagaman lainnya hingga lebih dari 76 tahun.

Pancasila, itulah istilah yang diberikan oleh presiden pertama Indonesia untuk menamai lima buah kalimat yang hingga saat ini dijadikan sebagai dasar Negara Kesatuan Republik Indonesia. Secara Etimologi, Panca beranti lima, sila berarti berbatu sendi, alas atau dasar, berasal dari bahasa Sansekerta yang juga berarti "pelaksanaan kesusilaan yang lima" (Darji Darmodiharjo, 1981)

Pancasila memiliki kebenaran secara nasional , dapat dilihat bahwa Pancasila merupakan suatu sistem filsafat yaitu memiliki kesatuan dari berbagai unsur yang memiliki fungsi tersendiri, saling keterikatan dan ketergantungan namun dengan tujuan yang sama. Sesungguhnya nilai-nilai Pancasila adalah dasar dan ideologi dalam bermasyarakat, berbangsa, dan bernegara, maka dengan memaknai kembali Pancasila itu merupakan sebuah penegasan terhadap komitmen tujuan negara.

Perkembangan teknologi akan selalu tancap gas kedepan tanpa menghiraukan rintangan dan tidak ada yang tau kapan hentinya. Tidak akan terbendung yang namanya resiko dari kemajuan teknologi ini. Layaknya arus air deras akan merembes ke sawah setempat dan merusaknya, sehingga dibutuhkan bendungan untuk mengendalikannya. Sama halnya dengan kemajuan teknologi ini yang membutukan bendungan ataupun filter sebagai pembuat batasannya.

Pancasila merupakan hal mendasar yang seharusnya menjadi pondasi didalam meniti ilmu pengetahuan dan teknologi, karena terdapat banyak nilai norma yang akan siap menjadi pelindung kita di dalam menikmati IPTEK. Nilai nilai norma ini akan menjadi filter atau penyaring, dan menjadi dasar untuk kita memilah dan memilih manakah yang memang seharusnya kita ambil. Pancasila tidak pernah membatasi kita di dalam melakukan kemajuan kemajuan yang nantinya akan menunjang dan juga mendukung Indonesia untuk menjadi bangsa yang maju. Tapi pancasila memfasilitasi kita dengan etika etika yang nantinya akan menjadi nilai tambahan bagi kita sendiri dan juga akan di pandang baik oleh siapa saja yang melihatnya.

Kamera yang seharusnya menjadi salah satu hasil pengembangan ilmu yang berfungsi untuk merekam objek tertentu menjadi sebuah gambar maupun video namun disalahgunakan dengan memanipulasi bentuk kamera menjadi bentuk tertentu dan umunya berukuran sangat kecil. Yang seharusnya kamera pengintai bisa digunakan untuk kegiatan positif, namun oleh karena pengembangan ilmu penggunaannya menjadi disalahgunakan.

Artikel ini membahas mengenai penyalahgunaan teknologi Spy Cam ( Hidden Camera ) yang sangat marak terjadi dan sering mengakibatkan pelanggaran hukum lainnya yang membuat penyimpangan terhadap nilai Pancasila. 


\section{RUANG LINGKUP PENELITIAN}

Artikel ini berusaha untuk menyatakan salah satu fakta terkait urgensi Pancasila dimasa sekarang ini. Bukan bermaksud ghibah, namun hal-hal seperti ini perlu diangkat ke rana publik supaya mucul pemahaman atau pengetahuan tentang dirinya dan keberadaannya ( Cambridge International Dictionary of English, 1995 : pengertian kesadaran ) .

Artikel ini berfokus pada penggunaan teknologi berupa kamera dengan berbagai macam bentuk dan ukurannya secara umum adalah sangat kecil ( $<50 \mathrm{~mm}$ ) yang dinamakan Spy Camera. Melalui pertimbangan dimana semakin meningkatnya kasus yang berhubungan dengan pornografi. Dan salah satu bentuk penyalahnggunaan Spy Camera ini adalah berhubungan dengan pornografi. Contoh kasusnya adalah perdagangan video seseorang atau lebih tanpa busana atau sedang melakukan kegitan yang sewajibnya adalah privasi bahkan sangat privasi.

\section{METODOLOGI}

Artikel berikut merupakan sebuah penulisan kualitatif yakni penelitian yang bersifat deskriptif dan cenderung menggunakan analisis. Teknik penulisan ini sangat tepat bagi penulis karena ketika proses pembuatan artikel ini dibuat oleh 3 orang penulis yang berada di wilayah Indonesia namun pada berbeda provinsi. Penelitian dokumen juga sudah sering dan sejak lama digunakan oleh peneliti untuk menguji, menafsirkan dan memprediksi.

Dokumen yang dimaksud adalah berupa jurnal online yang tersedia di website penyedia jurnal ( Google Scholar ). Masih dalam media yang sama yaitu media online, kebutuhan data/ informasi juga didapat dari artikel maupun berita.

Karena banyaknya sumber yang terdapat di media onlina ( terutama Google ), maka dibutuhkan cara berfikir yang logis, sistematis dan kreatif dengan tujuan untuk menyusun sebuah artikel yang hadir sebagaimana mestinya yakni artikel yang memuat fakta yang dapat meyakinkan dan mendidik serta menimbulkan kesadaran terhadap Pancasila sebagai dasar negara dan dasar pengembangan Ilmu. 


\section{PEMBAHASAN}

\section{Pancasila Sebagai Dasar Nilai Terhadap Ilmu Pengetahuan}

Pengertian Pancasila sebagai dasar nilai pengembangan ilmu pengetahuan dapat mengacu pada bebarapa jenis pemahaman. Salah satunya adalah bahwa setiap ilmu pengetahuan dan teknologi yang dikembangkan di Indonesia haruslah tidak bertentangan dengan nilai-nilai yang terkandung dalam Pancasila.

\section{Pentingnya Pancasila sebagai Dasar Pengembangan Ilmu}

Pentingnya Pancasila sebagai dasar pengembangan ilmu dapat ditelusuri ke dalam hal-hal sebagai berikut; Pertama, pluralitas nilai yang berkembang dalam kehidupan bangsa Indonesia dewasa ini seiring dengan kemajuan iptek menimbulkan perubahan dalam cara pandang manusia tentang kehidupan. Hal ini membutuhkan renungan dan refleksi yang mendalam agar bangsa Indonesia tidak terjerumus ke dalam penentuan keputusan nilai yang tidak sesuai dengan kepribadian bangsa. Kedua, dampak negatif yang ditimbulkan kemajuan iptek terhadap lingkungan hidup berada dalam titik nadir yang membahayakan eksistensi hidup manusia di masa yang akan datang.

Oleh karena itu, diperlukan tuntunan moral bagi para ilmuwan dalam pengembangan iptek di Indonesia. Ketiga, perkembangan iptek yang didominasi negara-negara Barat dengan politik global ikut mengancam nilai-nilai khas dalam kehidupan bangsa Indonesia, seperti spiritualitas, gotong royong, solidaritas, musyawarah, dan cita rasa keadilan. Oleh karena itu, diperlukan orientasi yang jelas untuk menyaring dan menangkal pengaruh nilai-nilai global yang tidak sesuai dengan nilai-nilai kepribadian bangsa Indonesia.

\section{Hakikat Pancasila Sebagai Dasar Nilai Pengembangan Ilmu}

Sila pertama, ketuhanan yang maha esa, sila ini memberikan kesadaran balrwa kita sebgai manusia hanyalah sementara dimuka bumi ini, yang diciptakan untuk berbuat kebaikan, dan tidak melakukan apa yang telah di larang untuk mendapatkan kehidupan yang kekal di akhirat nanti. Tuntutan etika seperti berprilaku bertanggung jawab, bersikap terhormat, menjunjung keselamatan. itu semua merupakan menifestasi untuk kebaikan. Dan dengan menjalankan itu semua merupakan wujud syukur atas nikmat Tuhan . Sila kedua, kemanusiaan yang adīl dan beradap memberikan arahan untuk perlakuan terhadap manusia haruslah sesuai dengan kodratnya yaitu bersosial, mempunyai kecukupan materi, mengajukan pendapat berperan nyata di lingkungannya dan terus berusaha dan kemanan yang tertinggi ( secara maksimal ). Sila ketiga, persatuan Indonesia. Professional dan seluruh masyarakat Indonesia harusah menjunjung nilai ini, karena kekurangan yang dimilki masing masing individu apabila digabungkan akan menjadi sesuatu produktifitas yang tinggi daripada jumlah individunya. Sila keempat, sila ini mengajarkan kepada kita bagaimana bekerja secara totalitas kepada Negara. Setiap orang memiliki hak dan kewajiban yang sama terhadap 
negaranya. Dan menejemen keputusan yang didasarkan oleh musyawarah akan memperoleh keputusun akhir yang terbaik karena melibatkan kerelaan dari semua pihak didalamnya. Sila kelima, keadilan sosial bagi seluruh rakyat Indonesia, sila ini mendasari agar tidak terjadinya jurang diantara warga Negara Indonesia. Dan para ilmuan dan dan para ahli selalu mengembangkan sistem dan juga seharusnya mengutamakan kesejahteraan karyawan nya. Selama ini perusahaan perusahaan besar hanya lehih mementingkan kepentingan di dalam memajukan kepentingan perusahaan, tanpa pula memerhatikan bagaimana kelayakan yang seharusnya diperoleh pula oleh para karyawanya

\section{Tantangan Pancasila sebagai Dasar Nilai Pengembangan Ilmu}

Adanya perkembangan IPTEK seperti memiliki dua sisi yang berbeda, disisi yang pertama IPTEK seakan membawa kepada kita kedunia yang serba bisa, dengan ses yang mudah dan kecanggihan yang tak perlu diragukan lagi. Namum, disisi lainnya kecanggihan dan segala yang mengagumkan dari IPTEK tersebut mampu menghardikan kita seakan menjadi manusia yang mampu di perbudak oleh apa yang diciptaknnya sendiri, disinilah kita akan mengetahui mengapa begitu pentingnya sosok pancasila yang akan menjadi dasar, diibaratkan bangunan. pancasila adalah pondasinya, Ilmu pengetahuan dan segala isinya adalah kemegahan dari bangunan tersebut, jika pondasi nya saja tidak kuat maka apalah arti kemegahan suatu bangunan. Pentingnya Pancasila sebagaidasar pengembangan ilmu dapat ditelusuri ke dalam hal-hal sebagai berikut. Pertama, pluralitas nilai yang berkembang dalam kchidupan bangsa Indonesia dewasa ini sciring dengan kemajuan iptek menimbulkan perubahan dalam cara pandang manusia tentang kchidupan. Hal ini membutuhkan renungan dan refleksi yang mendalam agar bangsa Indonesia tidak terjerumus ke dalam penentuan keputusan nilai yang tidak sesuai dengan kepribadian hangsa. Kedua, dampak ncgative yang ditimhulkan kemajuan iptek terhadap lingkungan hidup dalam titik nadir yang membahayakan cksistensi hidup manusia di masa yang akan datang. Oleh karena itu, diperlukan tuntunan moral bagi para ilmuwan dalam pengembangan iptek Indonesia. Ketiga, perkembangan iptek yang didominasi negara-negara Barat dengan politik global ikut mengancam nilai-nilai khas dalam kchidupan bangsa Indonesia, seperti spiritualitas, gotong royong, solidaritas, musyawarah, dan cita rasa keadilan.

\section{Masalah Penyalahgunaan Kamera Pengintai}

Contohnya adalah video viral aksi seorang pegawai Starbucks yang mengintip dada pengunjung lewat CCTV menjadi sorotan publik. Hal itu menjadi perbincangan banyak orang dan cukup menimbulkan kehawatiran di masyarakat. Pasalnya CCTV yang seharunya menjadi pelengkap keamanan di tempat publik malah disalahgunakan oleh oknum yang tidak bertanggungjawab.

Selain kamera CCTV, ada satu alat yang juga perlu diwaspadai oleh masyarakat untuk disalahgunakan terkait dengan ekpolitasi tubuh melalui video, yakni spy cam atau kamera 
mata-mata atau kamera pengintai. Masyarakat perlu mewaspadai adanya spy cam di fasilitas umum semacam toilet atau di tempat lain.

Spy cam merupakan kamera yang digunakan untuk mengintai atau memata-matai orang tanpa sepengetahuan mereka.Pakar Digital Forensik, mengatakan di luar negeri seperti di Amerika ataupun Asia, hal ini memang sering ditemukan. Bahkan di sana, sudah ada orang memproduksi dan kemudian dijual secara online video hasil mata-mata tadi. "Di beberapa negara baik itu di Asia maupun di Amerika hal tersebut sering terjadi."

\section{Beragam Rupa Dari Spy Cam}

Spy Cam adalah kamera pengintai atau kamera tersembunyi dengan bentuk camera yg di design berbeda dari umum nya cctv camera atau bentuknya sudah dikamuflasekan dengan benda lain, ada juga bentuk kecil lainnya yg dapat disembunyikan maupun dapat dikamuflasekan/dimodifikasi sendiri dengan benda lain.

Spy Camera belum mempunyai memori penyimpanan tersendiri, juga belum mempunyai sumber daya sendiri, dan utk media perekaman maupun agar terhubung ke jaringan internet tetap membutuhkan DVR.

Dan mengingat bentuknya yg kecil maupun tersamar, sampai dengan saat ini, semua tipe Spy Camera tidak dilengkapi Infared (IR).
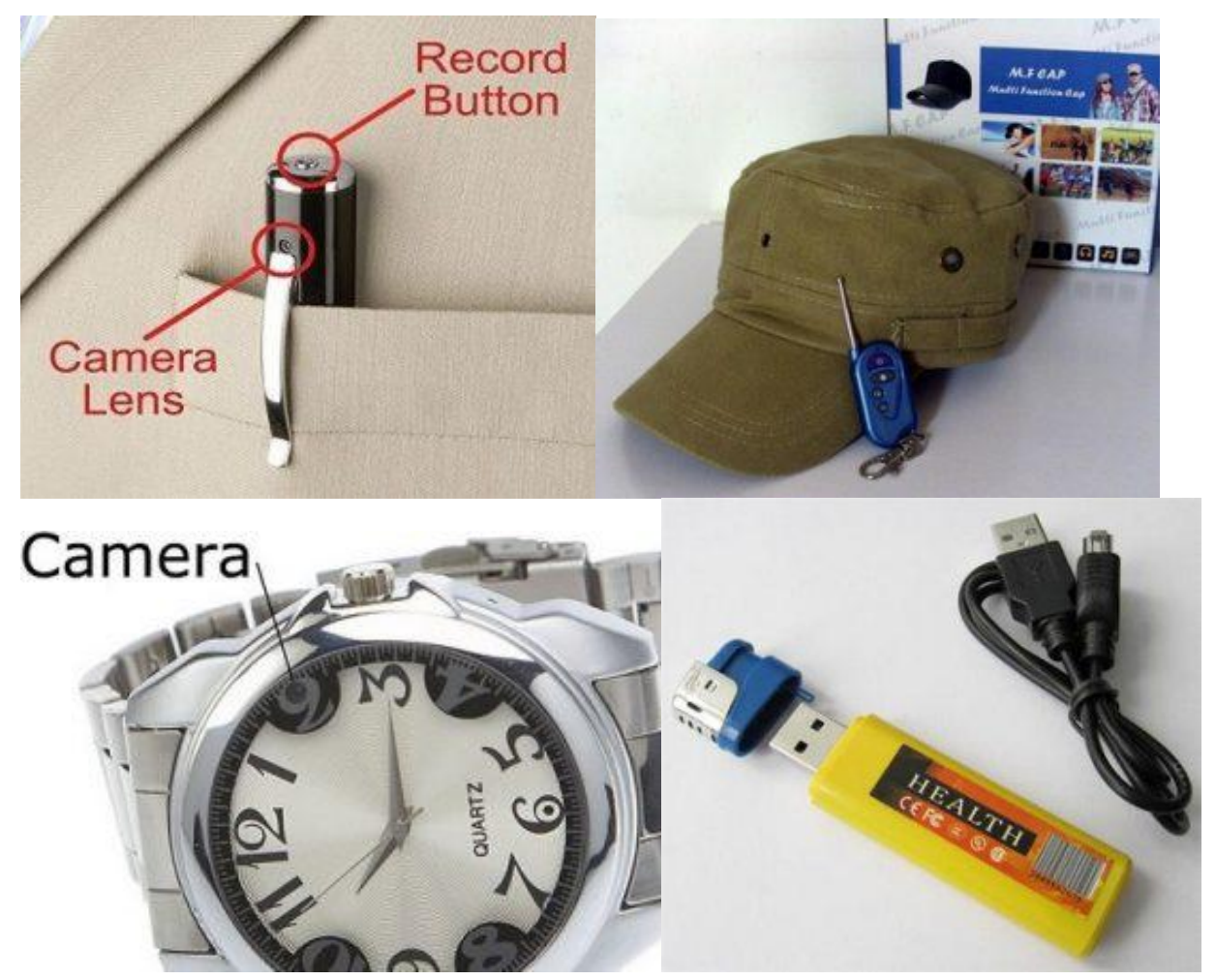

Gambar 1: Ragam bentuk Spy Cam 1. Pada Balpoint, 2. Pada Topi, 3. Pada Jam Tangan, 4. Pada Korek Api 


\section{Cara Mewaspadai Adanya Spy Cam}

Tanda adanya spy cam adalah ada semacam titik kecil kaca yang sebenarnya itu adalah lensa kamera. Lensa kecil yang dipasang tadi seringkali tidak disadari oleh orang awam karena memang bisa dikamuflasekan melalui benda-benda lain. "Salah satu tandanya adalah ada semacam titik kecil kaca, nah sebanarnya kaca itu lensa." Biasanya yang pasti terlihat mata korban adalah sebuah titik semacam kaca tadi yaitu lensa yang timbul, nah lensa itu tidak bisa disembunyikan tetapi badan kamera lainnya itu bisa disembunyikan. Spy cam biasanya diletakan dengan mengarah ke tempat yang menarik untuk dieksploitasi, Hal itulah yang perlu diperhatikan oleh masyarakat. Karena ukurannya yang kecil, Spy kamera mampu ditempel dan ditempatkan pada benda-benda lain yang sengaja dikamuflasekan."Di kaca mata, di pulpen, di gantungan kunci, apapun jenisnya itu bisa dipasang spy kamera,"

Bahkan ada juga yang pernah menemukan kasus spy cam terpasang dalam sebuah permen karet yang sengaja dikamuflasekan. Permen karet itu ditinggal dalam sebuah toilet, dan bagi orang awam mungkin akan mengira itu hanyalah permen karet biasa yang tertinggal, padahal di dalamnya ada spy cam. Di permen karet itu yang jaman dulu bentuknya panjang, itu bisa ditaruh pura-pura tertinggal di toilet, nah dia pakai battery dan pakai micro sd card, kacanya memang kelihatan tapi bagi orang awam itu hanya akan dikira permen karet biasa. Pada tempat lain, spy cam bisa juga diletakkan pada sebuah jam dinding, smoke detector ataupun spray pengharum ruangan. "Juga misalnya berbentuk semacam smoke detector tetapi palsu, disitu bisa juga dipasang spy kamera, atau bisa juga melalui spray pengharum ruangan tetapi diujung atau tengahnya itu dipasang kamera," Jadi memang luas atau memang banyak sekali variasinya," jadi kita harus berhati-hati dan waspada.

\section{Adanya Teknologi Spy Cam dan Pengaruhnya pada Nilai Pancasila}

Penemuan berupa kamera di saat awal penemuannya memang menuai banyak pujian, patut diakui karena sesungguhnya sejarah sangatlah penting disamping fungsi tulisan sebagai sumber utama sejarah. Pengambilan gambar juga turut memberi suasana baru jika dilihat kembali ( masa lampau ). Namun perkembangan teknologi yang semakin canggih menjadikan kamera yang dulunya sebagai alat mengenang atau untuk hiburan disalahgunakan menjadi media pembuat tindakan kriminal.

Bunyi sila kedua Pancasila "Kemanusiaan yang adil dan beradab " seakan dipatahkan oleh sebuah teknologi buah dari penelitian yang tidak singkat waktunya. Dicurinya privasi seseorang bukan hanya melanggar sila Pancasila namun juga menimbulkan trauma kepada korban terlebih lagi maraknya media sosial saat ini hingga menjadi banyak diperbincangkan masyarakat atau disebut viral. 


\section{KESIMPULAN}

Perkembangan teknologi dan informasi yang sangat pesat ini telah memicu perubahan kebutuhan dan gaya hidup masyarakat yang semakin lama semakin tergantung dengan teknologi. Perkembangan teknologi di kehidupan sehari-hari dapat dirasakan di hampir semua aktivitas.

Pancasila sebagai dasar nilai pengembangan ilmu pengetahuan dapat mengacu pada bebarapa jenis pemahaman. Salah satunya adalah bahwa setiap ilmu pengetahuan dan teknologi yang dikembangkan di Indonesia haruslah tidak bertentangan dengan nilai-nilai yang terkandung dalam Pancasila. Pentingnya Pancasila sebagai dasar pengembangan ilmu dapat ditelusuri ke dalam hal-hal sebagai berikut; Pertama, pluralitas nilai yang berkembang dalam kehidupan bangsa Indonesia dewasa ini seiring dengan kemajuan iptek menimbulkan perubahan dalam cara pandang manusia tentang kehidupan.

Adanya perkembangan IPTEK seperti memiliki dua sisi yang berbeda, disisi yang pertama IPTEK seakan membawa kepada kita kedunia yang serba bisa, dengan ses yang mudah dan kecanggihan yang tak perlu diragukan lagi. Namum, disisi lainnya kecanggihan dan segala yang mengagumkan dari IPTEK tersebut mampu menghardikan kita seakan menjadi manusia yang mampu di perbudak oleh apa yang diciptaknnya sendiri, disinilah kita akan mengetahui mengapa begitu pentingnya sosok pancasila yang akan menjadi dasar sebuah negara.

Salah satu bentuk hasil dari perkembangan teknologi adalah Spy Camera yaitu merupakan kamera yang digunakan untuk mengintai atau memata-matai orang tanpa sepengetahuan mereka dan didesain khusus dalam berbagai bentuk dan berukuran sangat kecil dibandingkan kamera pada umumnya. Tanda adanya spy cam adalah ada semacam titik kecil kaca yang sebenarnya itu adalah lensa kamera. Lensa kecil yang dipasang tadi seringkali tidak disadari oleh orang awam karena memang bisa dikamuflasekan melalui benda-benda lain.

Melalui artikel ini diharapkan kepada masyarakat terutama wanita agar selalu bijaksana dalam berbagai perjalanan dan disiplin berpakaian. Dengan itu akan semakin kecil kemungkinan seorang predator sex melakukan aksinya dalam hal ini menggunakan Spy Cam. 


\section{DAFTAR PUSTAKA}

Gesmi, Irwan. 2018. PENDIDIKAN PANCASILA.PONOROGO : UWAIS INSPIRASI INDONESIA

Situmeang.S.M.T (2021). PENYALAHGUNAAN DATA PRIBADI SEBAGAI BENTUK KEJAHATAN SEMPURNA DALAM PERSPEKTIF HUKUM SIBER. Unikom Bandung Amanda,Sylfida.N.(2018). PENGGUNAAN KAMERA PENGINTAI DALAM PEMBUKTIAN TINDAK PIDANA PEMBOBOLAN UANG DI ANJUNGAN TUNAI MANDIRI (ATM) (STUDI DI KEPOLISIAN DAERAH SUMATERA UTARA).UMSU Medan

Windasari.P.(2019). PANCASILA SEBAGAI DASAR NILAI DALAM PENGEMBANGAN ILMU PENGETAHUAN. Gorontalo

Anjarwati.Y.(2016). PANCASILA SEBAGAI DASAR PENGEMBANGAN ILMU PENGETAHUAN DAN TEKNOLOGI. Unsri Palembang 